\title{
SPATIAL AND TEMPORAL DYNAMIC OF URBAN GREEN AREAS IN NATAL/RN
}

\author{
DINÂMICA ESPACIAL E TEMPORAL DAS ÁREAS VERDES URBANAS EM \\ $N A T A L / R N$
}

José Luiz Alves Silva ${ }^{1}$ e Mário Tavares de Oliveira Cavalcanti Neto²

\begin{abstract}
Urban green areas are the coverage type that comes closest to the natural landscape. In this paper we aimed to evaluate three decades of spatio-temporal dynamic of green areas in the city of Natal and its administrative zones to answer how much green and urban coverage areas have changed, how much green area index has varied and when were such changes stronger. A remote sensing technique and a computer graphic program were used to convert, classify and extract information from Landsat satellite images from 1984, 1993, 2005 and 2015. Natal has lost 2/3 of its dense vegetation in the last three decades (currently ranging from $3 \%$ to $12 \%$ of its administrative zone areas). The green area index of the city was reduced from $107 \mathrm{~m}^{2}$ to $18 \mathrm{~m}^{2}$ of green area per inhabitant. However, major administrative zones had even lower indices than $18 \mathrm{~m}^{2}$ of green area per inhabitant. Changes in the coverage of vegetation and the green area index were stronger between 1984 and 1993. The results found out here are a first step to support decisions of stakeholders about land use and occupation in the city of Natal.
\end{abstract}

Keywords: Landscape changes; Remote sensing; Urban planning.

\section{RESUMO}

Áreas verdes urbanas são o tipo de cobertura que mais se aproximam da paisagem natural. Neste artigo objetivou-se avaliar três décadas de dinâmica espaço-temporal das áreas verdes no município do Natal e de suas zonas administrativas para responder o quanto as áreas de cobertura verde e urbana têm mudado, quanto o índice de área verde variou e quando tais mudanças foram mais fortes. Uma técnica de sensoriamento remoto e um programa de computação gráfica foram usados para converter, classificar e extrair informações de imagens de satélite Landsat de 1984, 1993, 2005 e 2015. Natal perdeu $2 / 3$ da sua área de vegetação densa nas últimas três décadas (variando atualmente de $3 \%$ a $12 \%$ da área das zonas administrativas). O índice de área verde da cidade foi reduzido de $107 \mathrm{~m}^{2}$ para $18 \mathrm{~m}^{2}$ de área verde por habitante. Contudo, a maioria das zonas administrativas tiveram índices ainda menores do que $18 \mathrm{~m}^{2}$ por habitante. Mudanças na cobertura da vegetação e no índice de área verde foram mais intensas entre 1984 e 1993. Os resultados encontrados aqui são um primeiro passo para subsidiar decisões das partes interessadas sobre uso e ocupação do solo na cidade do Natal.

Palavras-chave: Mudanças na paisagem; Sensoriamento remoto; Planejamento urbano.

Recebido em 01.12.2016 e aceito em 04.07.2017

1 Ecólogo. Doutorando em Ecologia. Universidade Federal do Rio Grande do Norte. Natal/RN. Email: luizecologia@gmail.com

2 Geólogo. Doutor em Recursos Naturais. Professor de Pesquisa e Prospecção Mineral do Instituto Federal de Educação Tecnológica Rio Grande do Norte. Natal/RN. Email: mariotavarescefetrn@gmail.com 


\section{INTRODUÇÃO}

Green areas cover a small part of landscapes in major urban centers in Brazil, although they are the coverage type that comes closest to the natural landscape with important environmental, social and economic functions (BARGOS; MATIAS, 2011). Green areas in cities shelter local biodiversity, provide thermal and water control and air purification, influence human health, and impact the economic value of neighborhoods as well (NIELSEN; KARSTEN, 2007; LONDES; MENDES, 2014; DAAMS; SIJTSMA; VLIST, 2016). Urban green areas are divided into categories depending on its coverage (vegetation and facilities), legal status (public or private), usage (e.g. recreation or landscape architecture), accessibility (open or restricted), conservation status (e.g. preserved or protected), and ecosystem function (BARGOS; MATIAS, 2011; PANDURO; VEIE, 2013). Thus, green spaces should not be understood as uniform environments, but rather as environments that set distinct goods and services and affect differently the urban area (PANDURO; VEIE, 2013). Due to this great importance, green area information must be considered in management and public decisions to achieve sustainable development in cities (GÓMEZ et al., 2011).

Despite that, the expansion of many Brazilian urban centers in the last decades has not meant an increase in environmental planning by governments in order to ally the local population growth with the maintenance of green areas. This lack of planning has resulted in a rapid suppression of public and private green areas in the Rio Grande do Norte state and other states in the northeastern Brazil. Half of the native coastal vegetation in the north of Rio Grande do Norte state, such as restinga forest and mangrove, have been converted into agricultural and urban areas along 30 years (1969 - 1999) (FRANÇA; AMARAL; PEREIRA, 2004). These changes also extended to its capital city, Natal. The initial expansion of Natal occurred due to an implementation of popular horizontal housing in the 1960s, but it has been replaced by a fast process of verticalization in the last decade (OLIVEIRA; NUNES, 2005). As well as Natal, Mossoro city in the countryside of the state also has experienced a low environmental status of green coverage area per inhabitant (ARRUDA et al., 2013). Worth to note is that changes in city landscapes are not only quantitative, but also qualitative regarding to the human life quality (NIELSEN; KARSTEN, 2007; LONDES; MENDES, 2014; DAAMS; SIJTSMA; VLIST, 2016).

Human life health has been shown to depend on the relationship between urban green areas and population size (NIELSEN; KARSTEN, 2007). The World Health Organization (2008) recommended a minimum availability of $9 \mathrm{~m}^{2}$ of urban green area per inhabitant to ensure human life quality. Recent developments in remote sensing techniques have been broadly used to estimate urban green areas and green area index worldwide (MELESSE et al., 2007; 
MACHADO; PEREIRA; ANDRADE, 2010, FERNANDES et al., 2011), and those information are used as references to assess the environmental quality of cities and the life quality of citizens.

Remote sensing techniques consider green areas as the absorbed infrared in a single image resolution element (pixel) that is taken by a satellite sensor (MELESSE et al., 2007; WARD; JOHNSON, 2007). The green area of a city $\left(\mathrm{m}^{2}\right)$ divided by its population size give us the green area index (FERNANDES et al., 2011; BERTINI et al., 2016). No formal information of this index is available for Natal or several capital cities in northeastern Brazil, resulting in a delay of data to support decisions of stakeholders about environmental issues. Previous investigations in Brazil have shown a decreasing in the green area index. For example, the green area index of Teresina city on Northeastern Brazil was reduced from 146 to $115 \mathrm{~m}^{2}$ of green area per inhabitant between 2000 and 2006, but this index is much lower nowadays (MACHADO; PEREIRA; ANDRADE, 2010). Curitiba city on Southern Brazil had $52 \mathrm{~m}^{2}$ of urban green area per inhabitant in 2007, and it is until the current days well known by its large green coverage spaces and its public politics for sustainable development (ECONOMIST INTELLIGENCE UNIT, 2010).

In this study, we aimed to evaluate three decades of spatial-temporal dynamic (between 1984, 1993, 2005 and 2015) of green areas in the city of Natal and its administrative zones to answer (1) how much green and urban coverage areas have changed, (2) how much green area index has varied, and (3) when such changes were stronger.

\section{MATERIAL AND METHODS}

\section{Study area}

The study was carried out in the city of Natal, Rio Grande do Norte state, northeastern

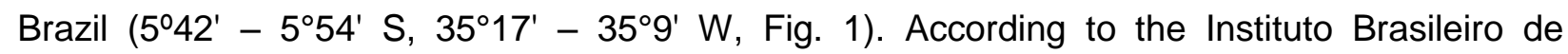
Geografia e Estatística (2015), the city is divided into four administrative zones (North, South, East, and West) that encompass around $168 \mathrm{~km}^{2}$ and a population size around 862,044 inhabitants. The climate is tropical with a severe dry season (PEEL; FINLAYSON; MCMAHON, 2007). Average annual temperature is $26^{\circ} \mathrm{C}$ and average annual precipitation is $1.746 \mathrm{~mm}$, concentrated between March and August according records of the Instituto Nacional de Meteorologia (freely available in http://www.inmet.gov.br/portal/). The remaining vegetation is a mosaic of herbaceous and shrub, surrounding broadleaf semi-deciduous vegetation patches of restinga forest. The Secretaria Municipal de Meio Ambiente e Urbanismo (2015) recognizes ten environmental protection zones with positive impacts on Natal city, such as Parque da Cidade and Parque das Dunas. 


\section{Data collection}

We used Landsat satellite images from CBERS Satélite Sino-Brasileiro de Recursos Terrestres (freely available in http://www.cbers.inpe.br/) to evaluate the spatial-temporal dynamic of green area of the city. We considered the best cloud cover condition for available images to form and analyze around three 10-years intervals. Images from 1984, 1993 and 2005 were taken by Landsat- 5 with 30-m side pixels and an image from 2015 was taken by Landsat- 8 with 50-m side pixels (UTM 25 South, Datum SAD 69, WGS-84, Orbit 214 and Point 64).

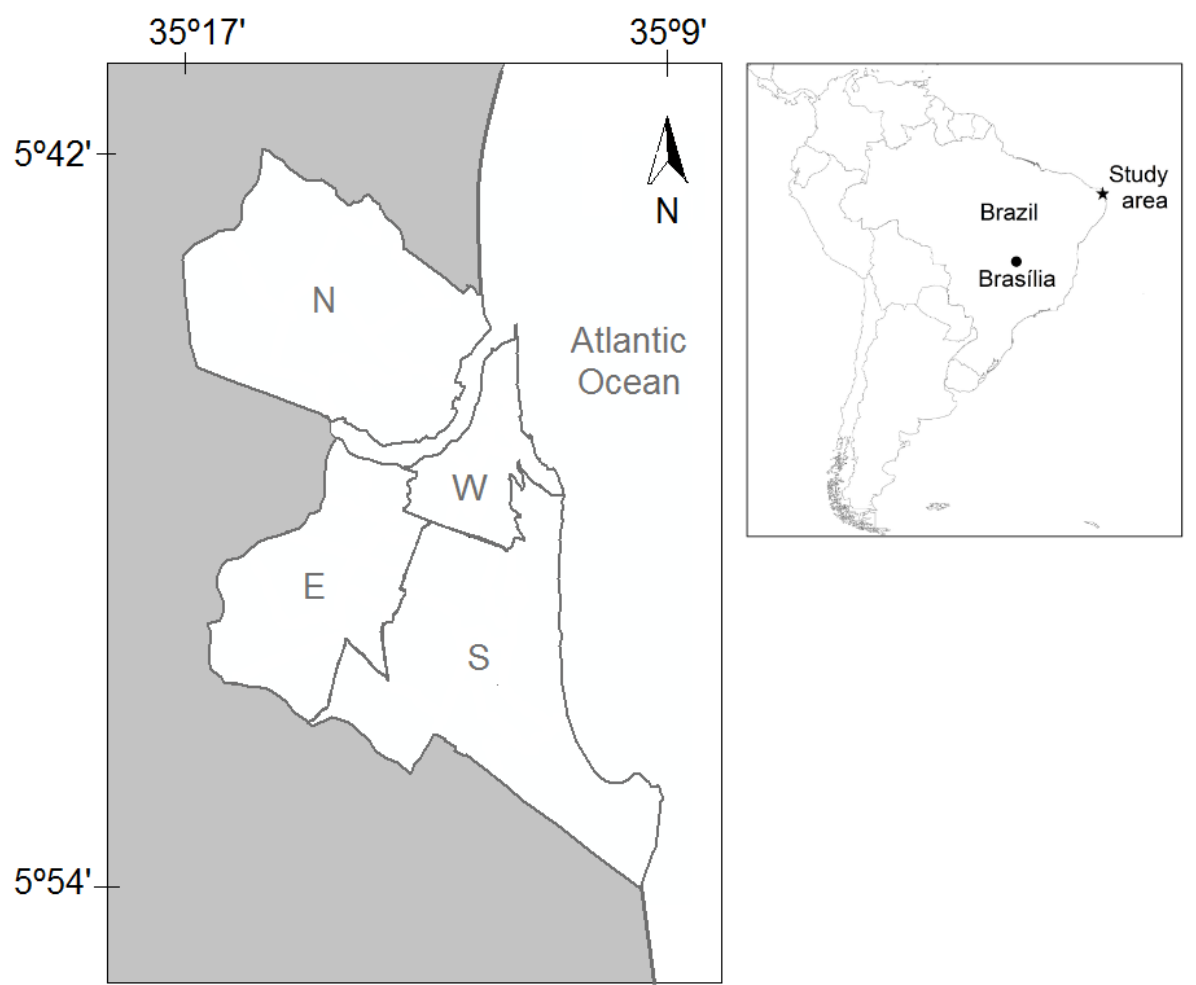

Figura 1. Localização geográfica da cidade do Natal e de suas zonas administrativas, estado do Rio Grande do Norte, nordeste do Brasil

Figure 1. Geographical location of Natal city and its administrative zones, Rio Grande do Norte state, Northeastern Brazil

After we contrasted and transformed the isolated bands (2, 3 and 4 bands) of each year into infrared images using ENVI 4.8 software, we classified them into five categories using the K-means supervised method, which were: flooded area, horizontal urban area, sparse vegetation (vegetation mixed with soil; e.g. herbaceous fields, gardens or pastures), dense vegetation (e.g. parks) and cloud coverage (Error). Dense vegetation was considered as all coverage that absorbed more infrared, e.g. canopy of trees and shrubs (MELESSE et al., 2007; WARD; JOHNSON, 2007). No mangrove area was considered in the analysis aiming to highlight just sparse and dense upland vegetation and to allow comparison among all administrative zones, because mangrove is just found in some of them. The files were exported to the free ImageJ program (available in https://imagej.nih.gov/ij/) to extract the coverage area 
information by each selected year from the whole city as well as from the four zones separately (Fig. 1), do not considering the Parque das Dunas area. This one was considered separately, following the city zoning plans.

\section{Data analysis}

We converted the number of pixels by category in each satellite image into $\mathrm{m}^{2}$ multiplying the total of pixels by $900(30 \times 30 \mathrm{~m})$ for landsat-5 images and by 2,500 $(50 \times 50 \mathrm{~m})$ for the landsat-8 image. The cloud coverage (Error) was subtracted in each image before we calculate the total of urban and green areas. After that we calculated the green area index dividing green area $\left(\mathrm{m}^{2}\right)$ by population size from a specific year considering sparse and dense vegetation (BERTINI et al., 2016). Population census from the Instituto Brasileiro de Geografia e Estatística are just available for few years in the last three decades, thus we considered closer years around 1984, 1993, 2005 and 2015 to get information of population size.

\section{RESULTS AND DISCUSSION}

As other capital cities in Brazil, Natal has been experimenting a deeply conversion of green spaces into urban areas (FRANÇA; AMARAL; PEREIRA, 2004; BARGOS; MATIAS, 2012; FERNANDES et al. 2011; BERTINI et al., 2016). For the last three decades Natal has lost $64 \%\left(\sim 36,178,900 \mathrm{~m}^{2}\right)$ of its dense vegetation. Fragments of dense vegetation covered $35 \%$ of the city in 1984 and have been reduced to $12 \%$ up to now (Figures 2 and 3). On the other hand, urban areas have increased $20 \%$ in coverage (from $38 \%$ to $58 \%$ ) with an increasing in population of 376,703 inhabitants. Sparse vegetation coverage has not changed along the years, except in the East administrative zone.

Only by analyzing the city pattern we could not properly answer how much green and urban coverage areas have changed up to now, because changes in landscape depended on the analyzed spatial and temporal scale. Patterns in the North and West zones of the city were much similar. The North zone has lost $85 \%\left(\sim 5,745,400 \mathrm{~m}^{2}\right)$ of its dense vegetation, which covered $40 \%$ of this zone in 1984 and was reduced to only $5 \%$ up to now (Figures 2 and 3 ). Urban areas have increased $29 \%$ in horizontal coverage (from $31 \%$ to $60 \%$ ) with an increasing in local population of 191,476 inhabitants. The West zone has lost $92 \%(\sim 4,148,800$ $\mathrm{m}^{2}$ ) of its coverage of dense vegetation. Fragments covered $38 \%$ of this zone in 1984 and have been reduced to only $3 \%$. Urban areas have increased $30 \%$ (from $35 \%$ to $65 \%$ ) with an increasing of 42,769 inhabitants. 

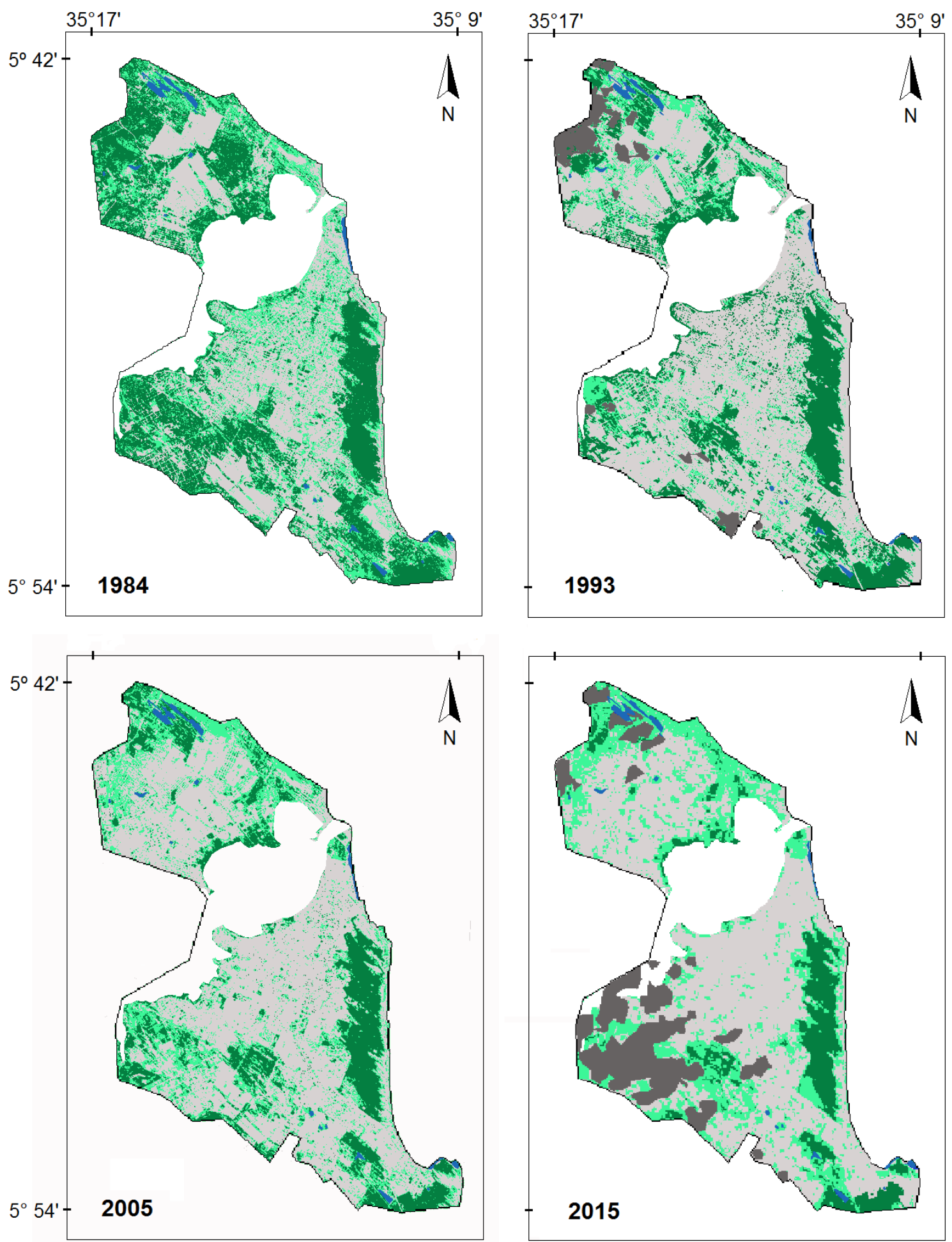

Figura 2. Mudanças na área de cobertura urbana (cinza), vegetação esparsa (verde claro) e vegetação densa (verde escuro) na cidade do Natal ao longo dos últimos trinta anos

Figure 2. Changes in the urban coverage area (grey), sparse vegetation (light green) and dense vegetation (dark green) in the city of Natal along the last thirty years 


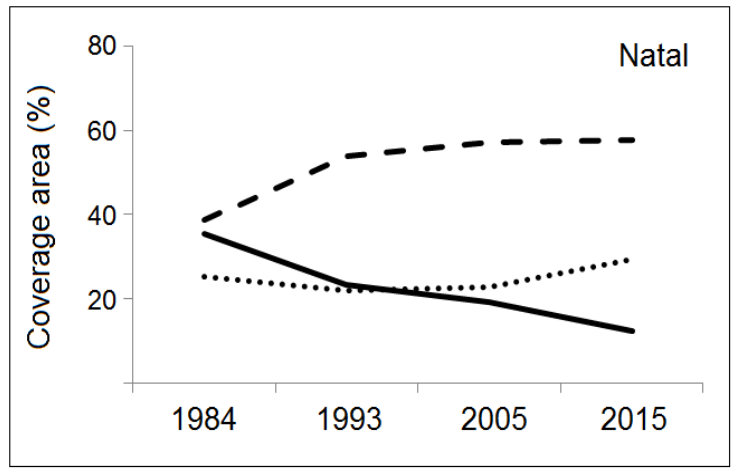

- Urban area

..... Urban vegetated area

- Natural vegetated area
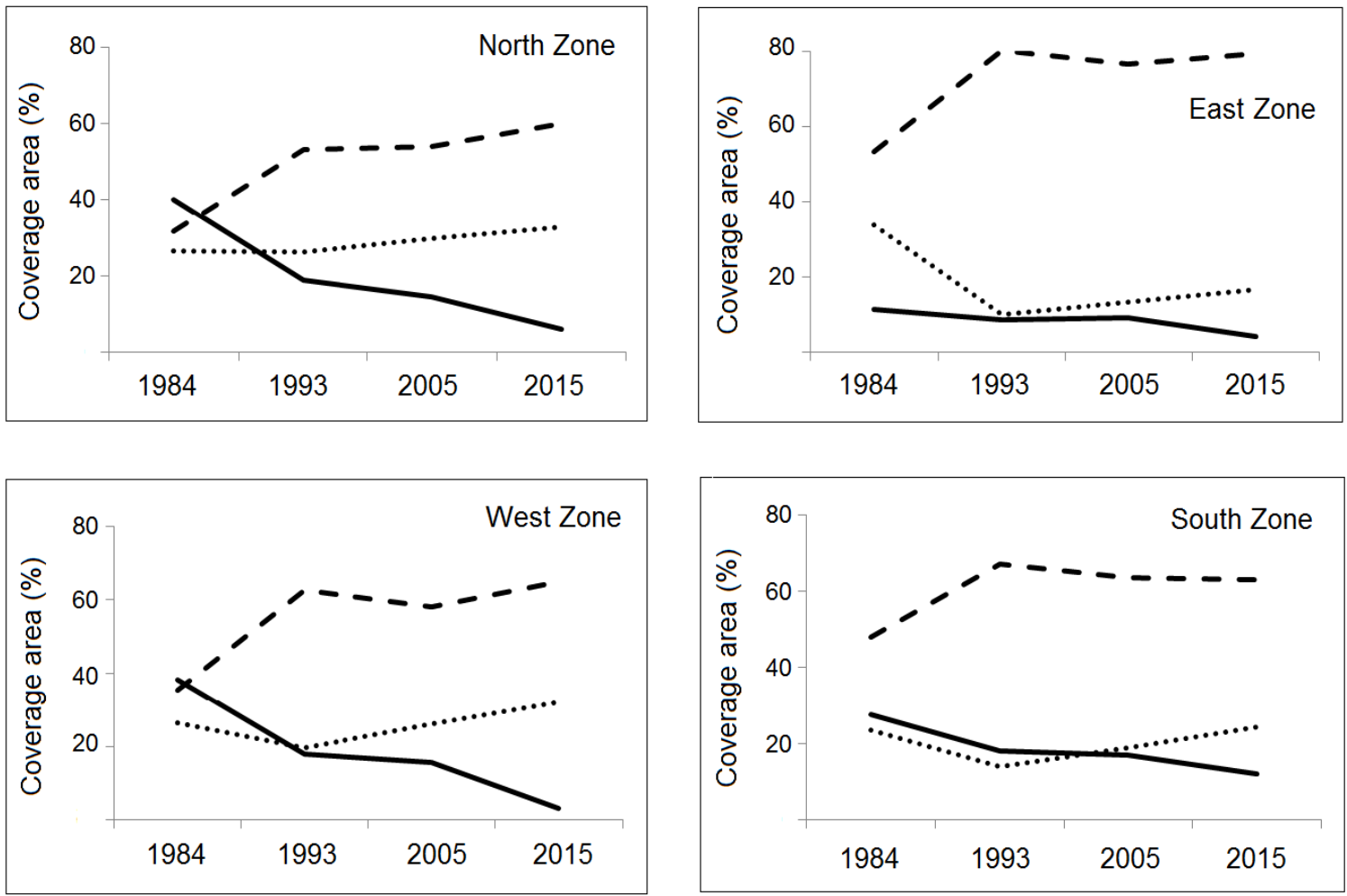

Figura 3. Porcentagem de área de cobertura urbana, vegetação esparsa e vegetação densa em Natal e suas zonas administrativas ao longo dos últimos trinta anos

Figure 3. Percentage of urban coverage area, sparse vegetation and dense vegetation in Natal and its administrative zones along the last thirty years

Historically with the highest urban coverage area of the city, East zone has lost $64 \%$ $\left(\sim 701,300 \mathrm{~m}^{2}\right)$ of its dense vegetation, which covered $11 \%$ of this zone in 1984 and was reduced to only $4 \%$ (Figures 2 and 3). Urban areas have increased $26 \%$ in horizontal coverage (from $53 \%$ to $79 \%$ ) with a decreasing in population of 10,871 inhabitants. Finally, the South zone has lost $56 \%\left(\sim 1,631,900 \mathrm{~m}^{2}\right)$ of its dense vegetation. Fragments of dense vegetation covered $28 \%$ of this zone in 1984 and were reduced to only $12 \%$. Urban areas have increased $15 \%$ in coverage (from $48 \%$ to $63 \%$ ) with an increase of 26,687 inhabitants.

Changes in the landscape of the city have not been only quantitative, but also qualitative regarding to environmental and human life quality (NIELSEN; KARSTEN, 2007; 
LONDES; MENDES, 2014; DAAMS; SIJTSMA; VLIST, 2016). Human comfort tends to decrease with verticalization, especially in tropical cities as Natal. Thus, urban planning must consider the natural wind circulation to regulate humidity and air temperature in such cities (AHMED; BHARAT, 2014). Natal city's microclimate has changed especially in the North zone between 1991 and 2011, which has been becoming the major zone of convergence of high temperature and humidity (ADALFRAN et al., 2012). No microclimate scenery has been projected to the North zone in case of the city zoning plan releases the verticalization process there. This is the only zone with restricted construction of high buildings, according to the Complementary Law $n^{\circ} 082$ of June $21^{\text {th }}$, 2007. Besides microclimate changes, quality and availability of water and soil resources and local biodiversity also decrease with the unplanned urban growth that in turn affect human life quality as well (NIELSEN; KARSTEN, 2007; LONDES; MENDES, 2014).

We also showed that Natal has decreased its green area index in six times in the last three decades, from $107 \mathrm{~m}^{2}$ in 1984 to $18 \mathrm{~m}^{2}$ in 2015 of green area per inhabitant (Figure 4). In some urban centers, it is hard to implement more dense vegetation areas. Thus, urban planning has to consider the sparse vegetation, such as herbaceous fields, gardens, public squares, or pastures, to improve urban and human life quality in cities. Considering the sparse vegetation in the amount of green spaces in the Natal city, the green area index reached $183 \mathrm{~m}^{2}$ of green area per inhabitant in 1984 and $62 \mathrm{~m}^{2}$ per inhabitant in 2015. Sparse vegetation facilitates the dispersion of individuals of native species among remaining dense-vegetation fragments. In addition to shelter local biodiversity, sparse vegetation also provides ecosystem services such as thermal and water control and air purification, that ultimately influence human health (NIELSEN; KARSTEN, 2007; LONDES; MENDES, 2014).

Although it remains unclear the effects of such changes in the citizens' health, recent researches in the human health area have shown that low green area index increase the stress and mean weight of a local population (NIELSEN; HANSEN, 2007). A minimum availability of 9 $\mathrm{m}^{2}$ of green spaces per inhabitant is recommended by The World Health Organization (2008) to ensure life quality in urban centers. We must not consider the actual $18 \mathrm{~m}^{2}$ per inhabitant in Natal as reasonable, because green coverage areas that influenced such rates are mediumsize fragments bordering the city such as Parque das Dunas or other environmental protection zones. Protection zones have an undoubted importance for the whole city, although it has limited influence in smaller scales into the urban center. 


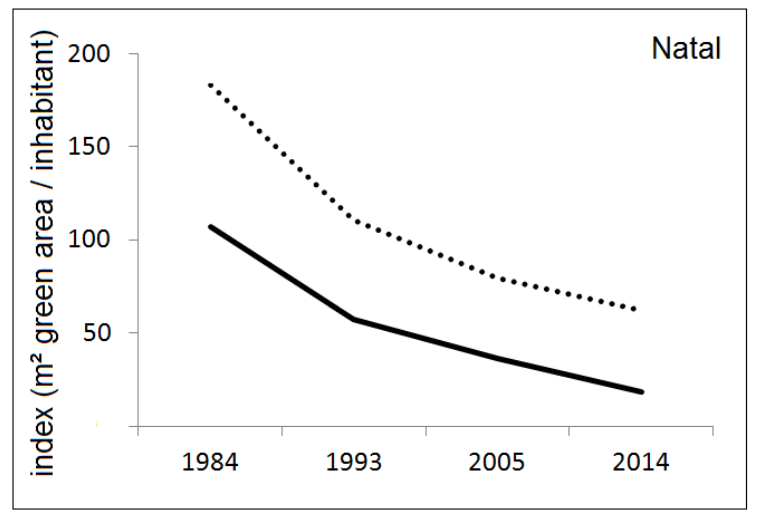

Natural+Urban vegetated area

Natural vegetated area only
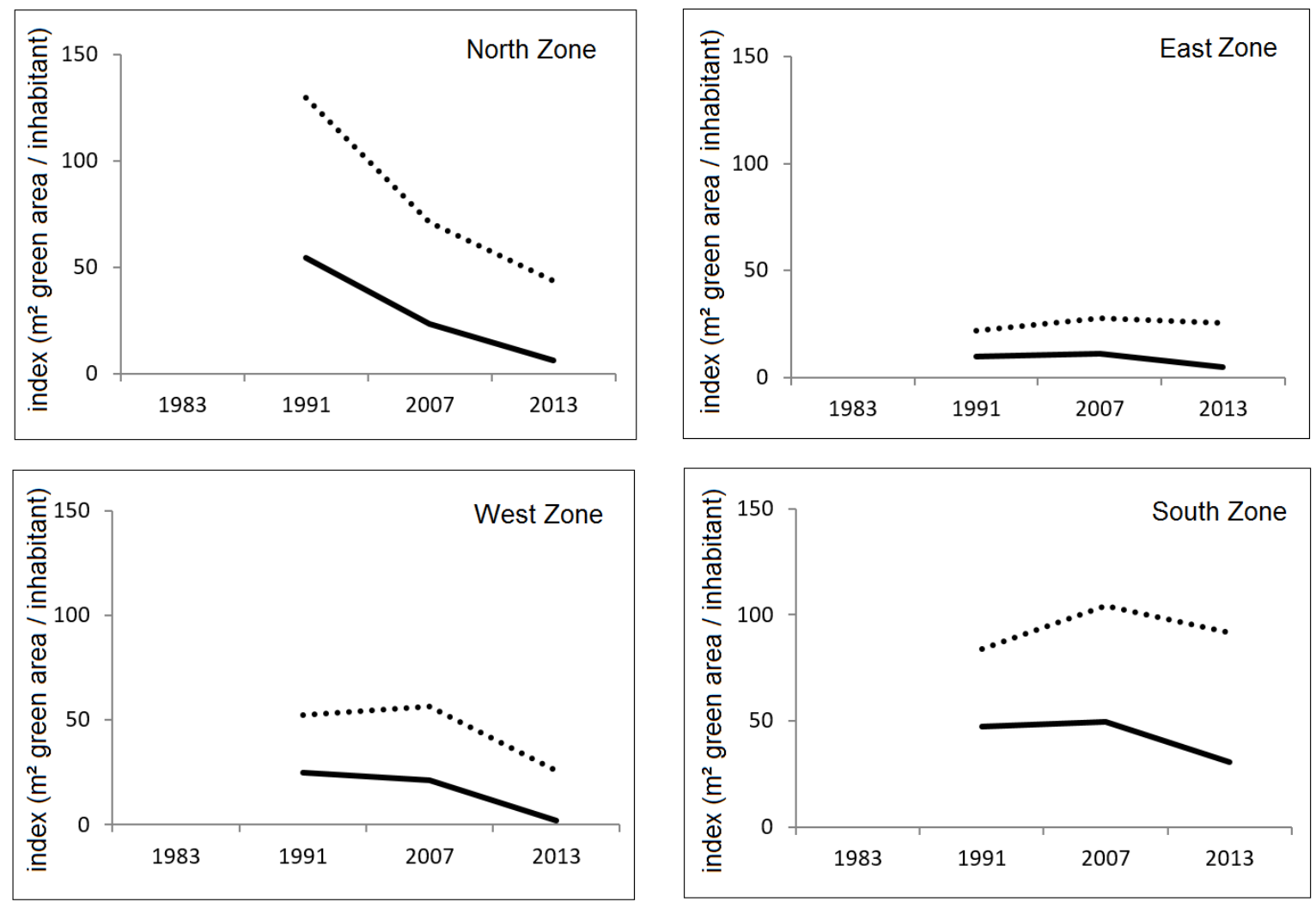

Figura 4. Área verde $\left(\mathrm{m}^{2}\right)$ por habitante (índice de área verde) do Natal e suas zonas administrativas, considerando áreas com vegetação esparsa e densa, separadamente de áreas com apenas vegetação densa

Figure 4. Green area $\left(\mathrm{m}^{2}\right)$ per inhabitant (green area index) of Natal and its administrative zones, considering areas with sparse and dense vegetation, separately from areas with dense vegetation only

To allow further investigation we calculated the green area index for the administrative zones separately. No information about population size from 1984 or closer years made impracticable any calculation of green area index of this year (Figure 4). The North zone decreased its green area index similarly as the city pattern, while changes in other zones were smoother. North zone showed a decreasing from $54 \mathrm{~m}^{2}$ in 1991 to $6 \mathrm{~m}^{2}$ of green area per inhabitant in 2013. The second highest decreasing in the index occurred in the West zone 
ranging from $25 \mathrm{~m}^{2}$ in 1991 to $2 \mathrm{~m}^{2}$ of green area per inhabitant in 2013. East zone had in average the lowest green area index, decreasing from $10 \mathrm{~m}^{2}$ in 1991 to $5 \mathrm{~m}^{2}$ of green area per inhabitant in 2013. The South zone had the highest green area index that decreased from $47 \mathrm{~m}^{2}$ in 1991 to $30 \mathrm{~m}^{2}$ per inhabitant in 2013. These results show that decisions of stakeholders about land use and occupation should consider different spatial scales of a city.

The time interval with stronger changes in the coverage of sparse and dense vegetation in Natal city was between 1984 and 1993, following the local culture of cutting down vegetation after land demarcation, and the implementation of popular horizontal housing after the initial expansion of the city in the 1960s (OLIVEIRA; NUNES, 2005). The urbanization process that occurred between 1969 and 1999 in the North of Rio Grande do Norte state decreased half of the native coastal vegetation by converting them into agricultural and urban areas (FRANÇA; AMARAL; PEREIRA, 2004).

\section{CONCLUSIONS}

We conclude that the city of Natal in Northeastern Brazil has lost $2 / 3$ of dense vegetation in the last three decades, which represents nowadays around $3 \%$ and $12 \%$ of its administrative zones. Green area index of the city has been reduced from $107 \mathrm{~m}^{2}$ to $18 \mathrm{~m}^{2}$ of green area per inhabitant, but this index is even lower than the recommended by the World Health Organization in the administrative zones $\left(2 m^{2}-6 m^{2}\right.$ of green area per inhabitant), except to the South zone ( $30 \mathrm{~m}^{2}$ per inhabitant). The time interval in which changes were more marked occurred between 1984 and 1993, motivated by a historical lack of planning on environmental issues. Decisions about land use and occupation of the city should consider different spatial scales.

\section{REFERENCES}

ADALFRAN, H. M. S.; SILVA, B. C. O.; JÚNIOR, N. P. C.; SILVA, F. M. Dinâmica espectraltemporal nos campos de umidade, temperatura e vegetação na cidade de Natal/RN por geoprocessamento. Revista Geonorte, Manaus, v. 2, n. 4, p. 1421-1432, 2012.

AHMED, A. S.; BHARAT, A. Designing the city according to the wind: using WAsP to minimize the impacts of high rise building complex on human comfort. International Journal of Innovative Research in Advanced Engineering, Hosur, v. 1, n. 5, p. 118-123, 2014.

ARRUDA, L. E. V.; SILVEIRA, P. R. S.; VALE, H. S. M.; SILVA, P. C. M. Índice de área verde e de cobertura vegetal no perímetro urbano central do município de Mossoró - RN. Revista Verde, Mossoró, v. 8, n. 2, p. 13-17, 2013. 
BARGOS, D. C.; MATIAS, L. F. Áreas verdes urbanas: um estudo de revisão e proposta conceitual. Revista da Sociedade Brasileira de Arborização Urbana, Piracicaba, v. 6, n. 3, p. 172-188, 2011.

BARGOS, D.; MATIAS, L. F. Mapeamento e análise de áreas verdes urbanas em Paulínia (SP): estudo com a aplicação de geotecnologias. Sociedade \& Natureza, Uberlândia, v. 24, n. 1, p. 143-156, 2012.

BERTINI, M. A.; RUFINO, R. R.; FUSHITA, A. T.; LIMA, M. I. S. Public green areas and urban environmental quality of the city of São Carlos, São Paulo, Brazil. Brazilian Journal of Biology, São Carlos, v. 76, n. 3, p. 700-707, 2016.

DAAMS, M. N.; SIJTSMA, F. J.; VLIST, A. J. The effect of natural space on nearby property prices: accounting for perceived attractiveness. Land Economics, Wisconsin, v. 92, n. 3, p. 389-410, 2016.

ECONOMIST INTELLIGENCE UNIT. Latin american green city index. Assessing the environmental performance of Latin America's major cities. Munchen: Siemens AG, 2010. $99 p$.

FERNANDES, N. M. S.; CAMPOS, S.; MOREIRA, K. F.; PISSARRA, T. C. T.; RODRIGUES, F. $M$. Análise do índice de cobertura vegetal da área urbana de Piratininga (SP). Ciência Geográfica, Bauru, v. 15, n. 1, p. 78-83, 2011.

FRANÇA, F. A. N.; AMARAL, R. F.; PEREIRA, D. A. Land use mapping and change detection assessment in the eastern littoral zone of Rio Grande do Norte state, Brazil, using GIS techniques. Journal of Coastal Research, Florida, v. 39, n. 39, p. 1635-1637, 2004.

GÓMEZ, F.; JABALOYES, J.; MONTERO, L.; DE VICENTE, V.; VALCUENDE, M. Green areas, the most significant indicator of the sustainability of cities: research on their utility for urban planning. Journal of Urban Planning and Development, Reston, v. 137, n. 3, p. 311-328, 2011.

INSTITUTO BRASILEIRO DE GEOGRAFIA E ESTATÍSTICA. Estimativas populacionais para os municípios brasileiros. Available in: <http://www.ibge.gov.br/home/estatistica/ populacao/estimativa2014/default.shtm> Accessed in: July 10 2015.

LONDES, P. R.; MENDES, P. C. A Influência das áreas verdes na qualidade de vida urbana. Revista Brasileira de Geografia Médica e da Saúde, Uberlândia, v. 10, n. 18, p. 264-272, 2014.

MACHADO, R. R. B.; PEREIRA, E. C. G.; ANDRADE, L. H. C. Evolução temporal (2000-2006) da cobertura vegetal na zona urbana do município de Teresina - Piauí - Brasil. Revista da Sociedade Brasileira de Arborização Urbana, Piracicaba, v. 5, n. 3, p. 97-112, 2010.

MELESSE, A. M.; WENG, Q.; THENKABAIL, P. S.; SENAY, G. B. Remote sensing sensors and applications in environmental resources mapping and modelling. Sensors, Basel, v. 7, n. 12, p. 3209-3241, 2007.

NIELSEN, T. S.; KARSTEN, B. H. Do green areas affect health? Results from a Danish survey on the use of green areas and health indicators. Health \& Place, Oxford, v. 13, n. 4, p. 839850, 2007. 
OLIVEIRA, F. F. G.; NUNES, E. Sensoriamento remoto na análise espaço-temporal da expansão da mancha urbana em Natal/RN (1969-2002). In: SIMPÓSIO BRASILEIRO DE SENSORIAMENTO REMOTO (SBSR), 12., 2005, Goiânia. Anais... São José dos Campos: INPE, 2005. p. 3871-3878.

PANDURO, T. E.; VEIE, K. L. Classification and valuation of urban green spaces - A hedonic house price valuation. Landscape and Urban Planning, Amsterdam, v. 120, n. 120, 119-128, 2013.

PEEL, M. C.; FINLAYSON, B. L.; MCMAHON, T. A. Updated world map of the Köppen-Geiger climate classification. Hydrology and Earth System Sciences, Göttingen, v. 11, n. 11, p. 1633-1644, 2007.

SECRETARIA MUNICIPAL DE MEIO AMBIENTE E URBANISMO. Anuário Natal 2014. Available in: <http://www.natal.rn.gov.br/semurb/paginas/ctd-102.html> Accessed in: July $1^{\text {th }}$. 2015.

WARD, K. T.; JOHNSON, G. Geospatial methods provide timely and comprehensive urban forest information. Urban Forestry \& Urban Greening, Amsterdam, v. 6, n. 6, p. 15-22, 2007.

WORLD HEALTH ORGANIZATION. World health statistics. France: World Health Organization, 2008. 110p. 